\title{
Borges: perspectiva metafísica de la ironía y el humor
}

Fecha de recepción: 31 de marzo de 2020

Fecha de aprobación: 25 de junio de 2020

\section{Resumen}

La relación existente entre la filosofía y Borges es inevitable. No por el hecho de su contacto con la cultura europea, sino por su perspectiva sensible del mundo en la cual lo experimenta a través de lo literario. Bajo la idea anterior, este artículo pretende establecer dicha relación. La intención de esta reflexión es abordar algunos relatos del escritor argentino, dialogando constantemente entre lo filosófico y lo teórico en relación con la ironía y humor. Se debe comprender a Borges desde otras miradas, una de ellas es la filosófica. De ello, la relación que se establece con la escritura tiene una profunda visión entre la metafísica e ironía en los relatos analizados. Borges conlleva la literatura y la filosofía con un diálogo permanente. Sus escritos están comprendidos desde dicha perspectiva analítica del mundo en la cual la ironía y el humor fino se intercambian para justificar su literatura.

Palabras clave: Literatura, filosofía, metafísica ironía, humor.

Citar: Abello Rayo .L. F. (julio- septiembre de 2020 Borges: perspectiva metafísica de la ironía y el humor. La Palabra,(38), 33-45.@it https://doi.org/ 10.19053/01218530. n38.2020.10820

Luis Fernando Abello Rayo

Universidad Tecnológica de

Pereira.

abellorayoluisfernando@gmail. com.

(iDhttps://0000-0001-6721-8985

* El presente artículo de reflexión fue presentado en la Maestría en Filosofía UTP, en el seminario de metafísica. 


\title{
Humor and Irony in Jorge Luis Borges from a Metaphysical Perspective
}

\begin{abstract}
The deep influence of philosophy in Jorge Luis Borges is widely known. The relationship between philosophy and literature is investigated in this paper as a way to present how Borges converts literature as an extension of philosophy. Through the concepts of humor and irony, works of this Argentinian writer are analyzed here to establish a vision of its metaphysics. The purpose of this paper is to reflect on how short stories of the Argentinian writer converge within the frameowrk of the relationship between philosophy and literature, seen from irony and humor. Borges must be understood from different approaches; one of them is certainly philosophy. From there, a relationship is established between philosophy and literature which analyzes in depth metaphysics and irony in his short stories. As Borges' writing is understood, in some way, by the prism of philosophy, this paper demonstrates an analytical approach to the irony and humor as part of the metaphysical point of view.
\end{abstract}

Keywords: Literature, Philosophy, Metaphysics, Irony, Humor.

\section{Borges: perspectiva metafisica da ironia e o humor}

\section{Resumo}

A relação existente entre a filosofia e Borges é inevitável. Não pelo fato de seu contato com a cultura europeia, mas pela sua perspectiva sensível do mundo, experimentada por meio da literatura. Com base nessa ideia, este artigo se propõe a estabelecer tal relação. A intenção desta reflexão é abordar alguns textos prosaicos do escritor argentino, dialogando constantemente entre o filosófico e o teórico em relação à ironia e ao humor. Deve-se compreender Borges a partir de outros olhares, sendo um deles a filosofia, uma vez que, nos relatos analisados, o relacionamento estabelecido com a escrita articula uma profunda visão entre a metafisica e a ironia. Borges mistura a literatura e a filosofia num diálogo permanente. Seus escritos são compreendidos a partir uma perspectiva analítica do mundo na qual a ironia e o humor se enlaçam para justificar a sua literatura.

Palavras-chave: literatura, filosofia, metafísica, ironia, humor. 
German Espinosa en su libro $L a$ liebre en la luna (1990) menciona que uno de los aspectos literarios de Jorge Luis Borges es su "humor metafísico", influenciado por Thomas de Quincey (p. 244). Esto podemos evidenciarlo en varios de sus escritos, en los que la configuración humorística se basa en el contraste dado por el autor argentino con su problema universal: la filosofía y el otro.

De esa manera, el uso de la reflexión filosófica está presente en varios de sus poemas y relatos, lo cual da cuenta de una fidelidad a ese compromiso con el pensamiento y la actividad misma de filosofar. Con ello, estamos de acuerdo con Julián Serna Arango (1990), cuando menciona: "Jorge Luis Borges ha sabido realizar la síntesis fecunda entre los valores universales de la cultura y esa inspiración mágica, ese recurso poético" (p. 3). Y es dentro de ese saber universal que Borges lo complementa con su función imaginaria y metafísica, en la cual el lector es una víctima que se involucra de manera inconsciente dentro de su propia realidad.

Cabe señalar que es innegable el valor estético tejido por Jorge Luis Borges; no obstante, aún buscamos neciamente, si sus escritos son totalmente ficcionarios o son una caracterización narrativa o poética, o también una teoría y un ensayo. Conso- lidar dicha caracterización ha llevado a que Jorge Luis Borges se mantenga vigente por una determinación asumida desde su conocimiento y su evidente acercamiento con la filosofía, puesto que, negar dicho acercamiento sería negar su propia literatura. Dado lo anterior, estamos de acuerdo con Malamud Goti (2012) cuando menciona que

Los cuentos y ensayos de Jorge Luis Borges contrastan la idea del universo con la noción de un ámbito limitado que llamo el mundo, y que es aquel en el que asignamos significados y así nacen los hechos y las cosas. (p. 68)

Esta noción de lo no infinito no es rechazada por Borges, sino que existe un problema propio. La complejidad de la existencia emerge de esa inexplorada interrogación sobre qué es el mundo y su elaboración estética de significados.

A causa de lo anterior, Paul Ricoeur llama a la variabilidad de significados dentro de un texto plurivocidad (2017, p. 13), la cual articula diferentes conexiones en disímiles ambientes del discurso (literario o no). Este conflicto se va a delimitar cuando nos enfrentamos a Borges, puesto que su lenguaje no es estático, sino que, corresponde a un pensador que conecta dudas metafísicas, bajo el manto literario. Esta articulación permite determinar sus realizaciones frente a sus temas expuestos. En otras palabras, conecta diferentes temas de manera sólida a un público, al parecer particular, para llamarnos de algún modo a filosofar.

Desde un punto de vista literario, los personajes de Borges son una metáfora dentro de otra significación metafórica. Es ahí donde sus relatos cobran una relevancia y se hacen concretos en sus casos particulares. El uso de recursos literarios sea vital para crear no un embellecimiento del lenguaje, sino una tensión, pues

Las verdaderas metáforas no se pueden traducir. Solo las metáforas de sustitución son susceptibles de ser objeto de una traducción que restauraría el significado literal. Las metáforas de tensión no son traducibles porque ellas crean su sentido. Esto no quiere decir que no puedan ser parafraseadas, sino tan sólo que la paráfrasis es infinita e incapaz de agotar el sentido innovador. (Ricoeur, 2017, p. 65)

Las metáforas de tensión se relacionan con la metonimia, pues pueden ser reincorporadas con otro lenguaje y se sustituyen, en Borges o en cualquier otro escritor que realiza metáforas adecuadas. Se sabe que al sustituirlas perdería todo el significado no solo de una oración, sino del relato mismo, por lo que el creador argentino se cuida muy bien de cometer una pretensión 
con el lenguaje, pues sabe que su refutación puede preguntarse por el mismo significado. Comprende que su arma es mortal, dado que crear sentido en estas mismas no pueden ser auxiliares sino significantes dentro de sus relatos y poemas.

En este sentido, el lenguaje de Borges está ligado con su relación con el pensamiento. El resultado se evidencia en la búsqueda de sentido como totalidad, sin abandonar su procedencia. Por lo tanto, asumir el pensamiento del argentino debe hacerse de una manera que reconfigure parámetros literarios universales.

Pero esos valores universales, a través de su contacto con lo filosófico, creó su metamorfosis literaria con un pasado y presente latinoamericano. Esa idea parece asombrarnos, puesto que en autores como Juan Rulfo o Gabriel García Márquez su literatura está cargada de una gran tradición oral, y que ellos, en su universalidad con el lenguaje, a través de lo mítico y universal, supieron transformarla en literatura escrita y convocar a numerosas tradiciones que siempre serán vigentes, reconocibles. En Borges la poesía gauchesca es una evidencia de ello, además sus personajes se refieren a las multitudes argentinas. A causa de lo anterior, Ortega nos dice: "es evidente que como toda obra mayor la de Borges actúa en un ámbito literario universal.
Pero igualmente ella actúa en la dinámica creativa de una cultura hispanoamericana". (1977, p. 257) No obstante, Borges no se resigna a su tradición, la cual es filosófica y no lo hace por lo que es justamente una herramienta irónica, y que posibilita explicar su propio universo literario.

La ironía se ejemplifica desde lo propio de la literatura. Borges atribuye a la vida esa ironía y la envuelve justificada desde lo imaginario. Somos el producto de nuestro pensamiento, por lo tanto, somos imaginarios. Pero para pensarnos o imaginarnos, debemos tener un vasto de realidad. Así se evidencia en el relato La última visita del Caballero Enfermo (1977), del autor Giovanni Papini, retomado por Borges. En este, se narra la historia del Caballero Enfermo y que el narrador asume su enfermedad física por su tez pálida, pero el Caballero explica que su enfermedad es su existencia. El tema general comprende la discusión de su condición, por lo cual el Caballero responde:

No soy un hombre real, con huesos y músculos, generado por hombres. No soy más que la figura de un sueño. Una imagen de Shakespeare es, con respecto a mí, literal y trágicamente exacta: ¡yo soy de la misma sustancia que están hechos los sueños! Existo porque hay uno que me sueña; hay uno que duerme y sueña y me ve obrar y vivir y moverme y en este momen- to sueña que digo todo esto. Cuando empezó a soñarme, empecé a existir: soy el huésped de sus largas fantasías nocturnas, tan intensas que me han hecho visible a los que están despiertos. Pero el mundo de la vigilia no es el mío. Mi verdadera vida es la que discurre en el alma de mi durmiente creador. (Borges, Ocampo y Casares, 1977, p.133).

De acuerdo con lo anterior, dicho relato del italiano es una evidente influencia de Borges con la narración Borges y Yo. Los dos dan cuenta de la existencia de un alter ego en la cual usualmente nombramos como mi otro yo. Entonces, cada uno padece o aparenta un sentido doble cuyas elecciones de la cotidianidad los conducen a ser el blanco de sí mismos.

Como nos sugiere Borges, en el relato mencionado anteriormente, el sentido es dejarse arrastrar de manera irónica por el otro yo. El drama humano se desarrolla en la elocuencia de alguno de los dos Borges. Cada uno está dispuesto a sacrificarse por el otro y reconocerse en dicha elección: "Sería exagerado afirmar que nuestra relación es hostil; yo vivo, yo me dejo vivir, para que Borges pueda tramar su literatura y esa literatura me justifica" (Borges, 1984, p. 808).

Con lo anterior, nos vemos impulsados a determinar el carác- 
ter de Ironía. En este sentido, aludimos a Milan Kundera, en su libro Los testamentos traicionados (1994), encuentra con la palabra al reconocer que la ironía se teje con el sentido del mundo, con su propio significado. La necesidad de encontrar este sentido por medio de la ironía impone razones para precipitarse con un alter ego, pues permite diversificarse en la idea de su yo. La ironía en este punto "puede tomarse aisladamente, dada una de ellas se encuentra en compleja y contradictoria confrontación con las demás afirmaciones, las demás situaciones, los demás gestos, las demás ideas, los demás hechos" (p. 215).

Es entonces la ironía, para Kundera, un asunto contradictorio no de forma sistémica ni de lenguaje, sino ontológico. Es por esto mismo que, Borges se apoya en manifestarse por medio del otro, pues el acontecimiento mismo, proyecta cierto curso irónico al no existir existiendo por medio de la palabra. Estas mismas circunstancias invitan a un llamado a definirse desde la alteridad.

Por otro lado, la ironía definida por Paul de Man (1994) es un consuelo que promete excusándose en función del lenguaje, de la palabra, pero al no ser estática, no puede definirse directamente, dado que no es un concepto propio.
La ironía en Borges no se reduce a una concepción estética, sino que, parte de la misma forma estética del lenguaje. De esta forma, la ironía del argentino permite tomar una distancia frente a su marco conceptual, pues sabe que advierte conjugarlo con la nada. En pocas palabras, Borges reconoce que su ironía no puede someterse a lo estático, pues es una simpleza no definida.

Por consiguiente, el tratamiento del lenguaje irónico de Borges está cerca a los planteamientos de Jankelevitch (1982), cuando afirma que: "la ironía es una de esas cualidades que resulta contradictorio atribuirse, porque su existencia sólo obedece a la pura movilidad de la vida" (pp. 153-154). Está claro que la condición para la ironía con Borges gravita en demostrar que no la hay. Pues el hecho paradigmático de su lenguaje con lo irónico se debe considerar el reconocer la palabra con esa movilidad.

Hay que tomar en cuenta que lo irónico no hace parte de dicha tradición lingüística, sino filosófica. El lenguaje justificado de la palabra encontrado en Gorgias, precisamente, reconoce la evidencia de ironizar la palabra del otro bajo el desarrollo del tejido lingüístico. Es así, que dicha ironía puede considerarse como un humor enfrentado al juego del mismo verbo cuando se resguarda en las cuestiones filosóficas.

\section{La metafísica y el humor}

Lo cómico y el humorismo son la forma en la que el hombre intenta hacer aceptable la idea insoportable de la propia muerte

(Eco, 1998, p. 45).

Para el filósofo Martin Heidegger (2014), la metafísica se haya más allá de la simple concepción ontológica y su relación con el ser, puesto que ello sería una ramificación de su estudio, sino que: "el preguntar metafísico tiene que ser en totalidad y debe plantearse siempre desde la situación esencial en que se halla colocada la existencia interrogante. Nos preguntamos, aquí y ahora para nosotros" (p. 1). La comprensión esboza la intención y compromiso de Borges con la totalidad, dado que su laberinto está cargado de su propia interpretación de la filosofía; es decir, de la realidad, debido a la universalidad de sus escritos y sus contemplaciones como escritor. Lo metafísico de Borges en su metáfora circular y bibliotecaria proyecta la negación de la muerte del pensamiento, no la muerte física en apariencia. Se niega a deshumanizar la sabiduría.

El qué es, problema esencial de la metafísica, Borges lo aborda no para responderlo, sino para multiplicarlo. Por ello, en varios de sus textos los espejos 
son un horror por las ilusiones generadas, por las cuestiones dadas, y que son una misma biblioteca en la cual el ser no puede escapar, pues alberga el espíritu humano. A lo anterior, el argentino nos dice:

Los hombres suelen inferir de ese espejo que la Biblioteca no es infinita (si lo fuera realmente ¿a qué esa duplicación ilusoria?); yo prefiero soñar que las superficies bruñidas figuran y prometen el infinito... La luz procede de unas frutas esféricas que llevan el nombre de lámparas. Hay dos en cada hexágono: transversales. La luz que emiten es insuficiente, incesante. (Borges, 1984, p. 469)

Para ilustrar esta relación entre la metafísica y el humor, tomamos las reflexiones de Julius Bahnsen en su texto Lo trágico como ley del mundo y el humor como forma estética de lo metafísico (2015), en el cual lo humorístico transfigura como algo estético, no como apariencia, ni ausencia, sino como una trasformación de lo estético, alejado de lo simplemente bello que se oculta en su apariencia de verdad. Además, el humor se presenta como puramente objetivo dado que se considera un alejamiento de la ingenuidad (p. 138).

Resaltando lo mencionado, lo metafísico hace hincapié a nuestra relación. No denota una hipótesis para caracterizar lo humorístico como una moda literaria, sino como una superación de esa totalidad objetiva. En consonancia con lo metafísico, Bahnsen (2015) menciona:

El «seco» metafísico, como tal, no es en absoluto humorista; pero el que no es más que humorista a secas, le hace fácilmente competencia al metafísico, exponiendo con desnudez la dialéctica real, en lugar de escamotear el serio aquelarre de la vida con la sutil telaraña de las veleidades de la lógica. (p, 141)

Según esta relación, entre metafísica y humor, está abordada por Borges desde la literatura bajo el examen del lenguaje. El argentino desmantela no lo oculto de la literatura, sino el alejamiento de esa lógica totalizante de la lectura misma, que se trasforma en literaria. La totalidad de Borges es metáfora en biblioteca, en un mundo paralelo, o en un punto que representa esa totalidad. Pero también crea una nueva conexión entre lo metafísico, pues su humor no es la risa contraproducente que se tiene en forma común, al contrario, es un humor basado en lo estético y en su posibilidad de resolución.

Este humor es alejado esencialmente de la risa, como lo ha reflexionado Baudelaire (1988), en la cual es producto de una noción humana alejada de un esencialismo racional. Así, la risa es un producto primitivo y que implica una debilidad ( $\mathrm{p}$. 18). Con esta noción y separación de la risa a lo humorístico, Borges toma distancia, pues unifica un encuentro, desde sus creaciones, lo racional en una identidad estable para captar una realidad alterna a la nuestra.

Ahora bien, la intervención sobre la creación de un universo puramente literario hace que los conceptos usados por el escritor argentino se conviertan no solamente en pura filosofía, sino que sea una reacción del lenguaje, al establecer un diálogo con lo literario y presentar los problemas filosóficos de manera reaccionaria con el arte. Es así que Borges no abandona su pasado literario, su pasado enciclopédico, sino que transforma la filosofía, transforma al lector, al lenguaje, y por sí mismo, busca un acercamiento con el símbolo metafísico a través de la risa y la estructura literaria.

Por otro lado, la analogía existente entre la alegoría de la Caverna y el relato Tlön, Uqbar, Orbis Tertius es inmanente, puesto que se corresponden a un compuesto de una ignorancia de un mundo externo, muy parecido al nuestro, pero que la única forma de conocerlo es burlándonos de nuestra propia situación. En la Caverna, los hombres están sujetos a mirarse a sí mismos encadenados, solo tienen la posibilidad de mover sus cabezas para ver el fuego que emana de la entrada de la 
caverna, por lo cual las imágenes observadas, limitadas como sombras, son su realidad. Es aquí donde aparece la imagen análoga a los espejos que causa la impresión de otro mundo externo; con lo anterior, Borges menciona: "debo la conjunción de un espejo y de una enciclopedia el descubrimiento de Uqbar" (1983, p. 21). Es decir, para Platón y Borges, las imágenes o su parecer son elementos de descubrimiento y sorpresa para crear un énfasis en la revelación de lo verdadero. Para los dos la realidad extrínseca es un acceso a la concepción de una realidad comunicable, porque es "una realidad atroz y banal" (1983, p. 21).

Es, entonces, el mundo una representación de la propia voluntad, el mundo sobre uno mismo es construido de nuestros ideales y nuestras representaciones hacia él. La asistencia la encontramos en nuestro interés racional, pero es un problema del conocimiento en sí. La valoración que hagamos de él es antigua, lo cual permite aclarar que su función ha estado presente desde la natalidad. Todo esto no es más que una forma de estar en el mundo, de estar representados. De lo anterior, Shopenhauer menciona:

Todo este mundo, es solamente objeto en referencia a un sujeto, intuición de alguien que intuye; en una palabra, representación. Natu- ralmente, esto vale, igual que del presente, también de todo pasado y futuro, de lo más lejano como de lo próximo: pues vale del tiempo y el espacio mismos, únicamente en los cuales todo aquello se distingue. Todo lo que pertenece y puede pertenecer al mundo adolece inevitablemente de ese estar condicionado por el sujeto y existe sólo para el sujeto. El mundo es representación. (2020/1819, p. 23)

La mirada que el griego y el argentino realizan desde diferentes tópicos se unifica dadas las circunstancias en las cuales no aceptan un mundo absoluto, permanente, condicionado. La reflexión en la interpretación del mundo no se realiza de manera empírica, mucho menos positivista de una reacción tenue y directa con la realidad. Los dos han comprendido la libertad que ello genera, y buscar el origen de esta no necesita una conformidad, sino que lo examinan bajo las consecuencias que están dispuestos a soportar.

Platón (1988, p. 338) en su diálogo 515a menciona que los hombres al ver la luz les irritarían los ojos, por lo cual su descenso a la caverna sería más estrepitoso. Por lo tanto, el mundo representado debe tener una pertinencia aguda para los sentidos y el conocimiento. Aquí se debe tener en cuenta que la traslación de un mundo representado y uno que voy a representar solo tiene cabida hacia lo atroz, y el escrutinio del mismo.

Ahora bien, el mundo representado, específicamente, en Borges es una biblioteca de innumerables números que se repiten, incesantemente, pues es la filosofía, su retórica, su forma de ver el mundo que ha causado su confusión. De modo que, ella "ha contribuido a multiplicarlo" (1983, p. 31). Es entonces, que surge como una recuperación no lineal del pensamiento humano en Tlon, sino que su renovación con poetas, filósofos, moralistas, etc., alude al escape de este mismo mundo contemplado desde las sombras. Borges nos muestra que dicho mundo -el nuestro- está condicionado desde una universalidad de conocimiento, y es por lo que la biblioteca, aunque contenga un saber universal, sugiere que la satisfacción de un hombre está en su memoria, pero que esa memoria es frágil para salir de la caverna.

Borges nos insta a pensar el mundo desde su representación intelectual bajo el mando memorístico, pero que su fragilidad se combate con lo simple. Por ello "un libro que no encierra su contralibro es considerado incompleto" (Borges, 1983, p. 35). El contralibro es referido a su opuesto de cada libro almacenado en la biblioteca Uqbar. Es decir, su antítesis. La indagación realizada por Borges permite saber cuál es su 
intencionalidad con su relato, pues da lugar a una formación entretejida por lo contrario a lo materialista e invita a poner en duda el conocimiento universal

En otras palabras, salir de dicha caverna platónica y borgeana significa conocer y des-conocer, desprendernos del mundo y transformarlo con nuestra voluntad representativa de él.

Lo anterior, se puede evidenciar en Funes el memorioso, en el cual Borges, en primera persona, narra la sucesión de hechos inmemorables a finales del siglo xix por parte de dos sujetos que se convertirán en antítesis misma de la memoria. Por tal razón, quien narra la historia es un sujeto que constantemente está describiendo los hechos, pero no de forma comúnmente narrativa, sino que precisa en el verbo recordar, a lo cual la memoria de este primer personaje se enfoca en las particularidades del encuentro con Funes. Por otro lado, Funes se le observa, en principio, una memoria particularizada de hechos históricos, para que posteriormente se acerque a las conveniencias de las generalidades de la memoria, producto de su encierro.

En primer lugar, la revelación de la memoria no tan selecta por parte de Funes está fundada por su estancamiento en "otra caverna" por haberse tullido, es entonces que "su percepción y su memoria eran infali- bles" (Borges, 1983, p. 101). Nuestra acotación a esta cuestión de la memoria resulta un enfrentamiento con las obras mencionadas en el libro vii de la República, pues su peripecia memorística se convierte en su absoluto mundo, con lo cual, haber conocido el mundo por medio de la palabra y la lectura, se desprende de este mismo metafísicamente, pues se pregunta por el espacio vivido con su memoria de lo simple.

Acá es donde se rompe el lazo con Shopenhauer, pues el mundo conocido, el externo, se va pulverizando; es decir, haberlo experimentado, aun cuando lo hemos conocido por propia voluntad, va desapareciendo y con él nuestras consideraciones. De ello, nos posicionamos a exclamar "el mundo es independiente de mi voluntad" (Wittgenstein, 2020, p. 98). El sentido en este relato es inmanente no solo a la memoria, sino al asunto del sujeto dentro de su caverna, pues postula otra idea del conocimiento y que le daría razón frente a la filosofía idealista y su lenguaje diacrónico.

Aunque en el relato se asuma que Funes no pensaba, sino que era asunto propio del recuerdo, ausente de ideologías, pues ya sus recuerdos hacían parte de lo específico y no de lo general (Borges, 1983, p. 103), como en Platón, Funes utiliza la confrontación al mundo con lo imperceptible, con lo poco sensible de otra realidad alterna, unilateral, constituyendo para sí un campo de reflexión inmanente en el que sus juicios emiten su mundo. Por otro lado, Borges, en el mismo relato, ha estado ironizándonos a través de la lectura, consolidando lo inverosímil de la memoria. En este, el narrador nos cuenta, de manera insistente, el recuerdo de los lugares, las imágenes, que lo atraen estéticamente, para lo cual tiene una especie de revelación cuando conoce a Funes, pues son polos opuestos. Borges no ha querido decir que Funes y él son una misma persona, proyectada desde el mismo espacio, y que no habido lugar para separarlos sino su encuentro.

Lo anterior, hace que nos veamos impulsados a caer en el juego borgeano, en el que hemos sido abordados desde una síntesis semántica desde el primer momento, pues en una líneas, escritas en latín "ut nihil non iisdem verbis redderetur auditum" (Borges, 1983, p. 99), menciona que las palabras no pueden restaurar a la audiencia; es decir, que la advertencia mencionada no nos puede causar repudio sino una ironía en nuestra capacidad interpretativa. Las insinuaciones que realiza Borges con nosotros no pueden dirigirse contra una teoría simplemente, sino que van directo a confrontar al lector, por lo tanto, una lectura de manera ortodoxa va a caer por su 
propio peso en sus consecuencias irónicas.

Así lo podemos ver en el relato "Tlön, Uqbar, Orbis Tertius". Dicho relato nos hace una sugerencia, como en muchos de sus escritos, de lo que va a suceder: nos hace una entrada hacia un universo posible de manera metafísica, mencionando que va a ser "la adivinación de una realidad atroz y banal" (Borges, 1983, p. 21). Desde ahí, la relación va a ser constante con un universo, aparentemente, desconocido para nosotros, una especie de biblioteca imaginaria donde los espejos multiplican a los hombres y son un horror. Todo esto en la literatura de Uqbar y el otro mundo Tlön, en otra realidad con autores que hemos abordados y que hemos escuchado: Espinoza, Platón... esos autores no son definitivos, sino que yacen en un mundo que debemos construir, un mundo imaginario, un mundo borgeano, y al perdernos en la lectura, debimos comprender desde el inicio que el mundo de Borges es nuestro mundo.

A eso se refiere Serna Arango (2014) cuando nos habla de una filosofía que no es literaria, pero utiliza todos sus recursos. Ahí nace la doble risa metafísica: su estética nos da la posibilidad de que "el ser puede ser hecho temático y llevado al lenguaje, entonces -y solo entonces- es posible la metafísica" (Coreth, 1972, p. 223). Ese lenguaje transformado en una especie de risa parca convierte el horizonte del lector en una determinación ligada por la risa, pero una risa racional, puesto que el lector da su relación cómica al terminar su lectura y tal vez, esa risa intelectual busque "devaluar el valor negativo del sufrimiento" (Stern, 1950, p. 214).

Cabe resaltar que Borges no se burla de lector, sino que crea asuntos filosóficos de manera literaria. Tal vez es un asunto de forma en el cual la filosofía es concreta en sus preguntas y la literatura las plantea de una forma desprovista de cálculo. En ese tratamiento literario, es donde debemos abordarla y la atención borgiana en su estética despersonaliza el sentido mismo de la pregunta.

Inmersos en él no nos queda otra salida, sino continuar el camino trazado desde el inicio del relato, puesto que dicho mundo es nuestra contemplación: "Tlön será un laberinto, pero es un laberinto urdido por hombres, un laberinto destinado a que lo descifren los hombres" (Borges, 1983, p. 42).

Con lo anterior, se pone en evidencia que la posición que toma Borges en sus escritos no yace en la simple anécdota, o incluso en un relato erudito, pues la dialéctica que consigue el escritor argentino nos devela, con una dimensión irracional, en su razón de conocimiento. Es así como, el lector de Borges debe estar predispuesto a ascender a la burla, la ironía y demás elementos que constituyen indudablemente sus escritos. De ello, el mundo de Tlön utiliza "la ironía [que] nutre con esmero los elementos paródicos del relato $\mathrm{y}$ en ocasiones se incrementa con la incorporación de datos comunes" (Martin, 2004, p. 49).

A partir de dicha lectura, comprendimos el carácter metafísico de Borges es su accionar creador de nuestro universo y su realidad, pero lo es también en un humor, en una sátira, que nos ha interpuesto una tarea de crear a Tlön, descifrarlo, y que ese mundo, el vivido, más que un sueño, es la creación de Borges: somos el proceder de Borges.

Otro de los relatos que nos causa impresión por su relación con la metafísica, y con su circularidad de mundos fue $E l$ Aleph. En dicho relato, al igual que Tlön, nos da la necesidad de observar en lo mínimo la realidad, los mundos que confluyen en uno: un punto que confluyen otros. En este caso, es un objeto encontrado en el sótano de un amigo que contiene un universo y a la vez todos. Dicho objeto vuelve a crear la noción metafísica del poder y su creación. Aunque Borges no es el dueño del Aleph, sí le da una caracterización propia, a describir su (nuestra) realidad con el objeto después de contemplarlo: 
"En la calle, las escaleras de la constitución, en el subterráneo, me parecieron familiares todas las caras. Temí que no quedara una sola capaz de sorprenderme, temí que no me abandonara jamás la impresión de volver" (Borges, 2016, p. 207). Sobreviene entonces una gran fascinación de Borges por concluirnos que ese mundo también es el nuestro y, a su vez, hace parte de su mundo, dando la impresión de atribuirle al Aleph características precisas de toda su intervención con nuestra realidad.

El desenlace de este relato borgeano se encuentra en el preciso instante de la primera página, dándonos a conocer que va a ser una serie de sucesos modificados, cambiantes, y que serían infinitos. Es decir, otra vez nos hizo parte de sus ramificaciones y nos ha evaluado desde el principio, advirtiéndonos que la temporalidad existente entre sus escritos y nuestro mundo está ligado por una línea delgada de realidad metafísica. En otras palabras, se ha cumplido lo que Borges (2012) ha dicho sobre la metafísica y es "motivar esa lúcida perplejidad que es el único honor de la metafísica" (p. 70). La incertidumbre que sintetiza sobre la metafísica es el asombro que reaparece es sus fragmentos, por lo cual, es un llamado hacia una nueva revisión de la lectura, de sí mismo y de preguntarnos necesaria- mente por nuestra disposición a someternos a él.

Esa perplejidad observada desde los inicios de dichos relatos es lo que hace la intervención de Borges con la literatura universal, dada a su precisión de un proceso literario y filosófico. La trasmisión de sus visiones no debería parecernos novedosa, puesto que nos habla de un universo conocido, pero se crea con una exactitud que es expandida por esa incertidumbre de confrontarnos en su juego y posteriormente inspeccionamos si estamos ante nuestra realidad o su metafísica creadora. Ernesto Sábato (1995) nos da una apreciación más exacta a nuestra intención:

En rigor, creo que todo lo ve Borges bajo especie metafísica: ha hecho la ontología del truco y la teología del crimen orillero; las hipóstasis de su Realidad, suelen ser una Biblioteca, un Laberinto, una Lotería, un Sueño, una Novela Policial; la historia y la geografía son meras degradaciones espacio-temporales de alguna eternidad regida por un Gran Bibliotecario. (p. 10)

Por otro lado, está el relato Pierre Menard, autor del Quijote (2016). La sola idea de pensar que existe otro autor del Quijote nos hace dudar de nuestra misma existencia lectora, causante de nuestra risa. La pretensión de este título llama la atención acerca de las consecuencias de otro autor de dicha obra. Justamente en esto consiste uno de los rasgos distintivos de Borges: la ironía y el alter ego, ya abordado con anterioridad.

Como resultado de otro Quijote, particulariza la obra hacia el lector, no como una negación arbitraria, sino, todo lo contrario, la dispone desde otras fuentes interpretativas. En este asunto paradójico debemos decir que: "una paradoja demuestra que nuestra comprensión de algún concepto básico o un conjunto de conceptos crucial está viciado, que los conceptos se descomponen en casos límite" (Barise y Etchemendy, 1987, p. 4).

Es así como, en dicha creación paralela hay dos autores, en diferentes épocas de El Quijote, mostrándonos esta diferencia valorada desde un punto de vista teórico y estilístico: "es una revelación cotejar el don Quijote de Menard con el de Cervantes. Éste, por ejemplo, escribió (Don Quijote, primera parte, noveno capítulo):

...la verdad, cuya madre es la historia, émula del tiempo, depósito de las acciones, testigo de lo pasado, ejemplo y aviso del presente, advertencia de lo por venir.

Redactada en el siglo diecisiete, redactada por el "ingenio lego" Cervantes, esa enumeración es un mero elogio retórico de la 
historia. Menar, en cambio, escribe:

...la verdad, cuya madre es la historia, émula del tiempo, depósito de las acciones, testigo de lo pasado, ejemplo y aviso del presente, advertencia de lo por venir." (Borges, 1983, p. 62)

La expresión "en cambio", usada corrientemente para marcar o denotar una diferenciación entre dos o más argumentos, es usada por Borges magistralmente para provocar una doble lectura nuestra, puesto que siempre devolvemos la página para buscar una pequeña diferencia, que se empieza por buscar palabras, conceptos diferentes, y al no encontrar una coma, un punto o una tilde que los diferencie, no nos queda otro camino que sentirnos moldeados por esa intensión.

Esto nos lleva a observar el ensayo "Magias parciales del Quijote", publicado en el libro Otras Inquisiciones, en el cual nos afirma que "Cervantes no podía recurrir a talismanes o a sortilegios, pero insinuó lo sobrenatural de un modo sutil, y, por ello mismo, más eficaz" (Borges, 2001, p. 47). Acá nos plantea el esbozo de su idea, en la cual ha sorteado la lectura de Cervantes, pues para mostrar efectivamente una realidad de manera crítica, no es necesario elaborar a modo de lenguaje artilugios que conlleven al lector a una pesadez mental, sino que El Quijote es mordaz por su lenguaje preciso y su postura de la realidad inmediata, que contrasta con su contexto de autor.

En otras palabras, mencionar un pasado sin buscar el asombro inmediato del lector, sino la sorpresa del mismo, es la intención, a lectura de Borges, de $E l$ Quijote. Consideramos que la lectura que realiza el argentino del español es sutil; es decir, cuidadosa y que su significado en relación con el relato nos deja entrever que sus ensayos están en sus relatos o viceversa. Evidenciando el final de su texto sobre El Quijote, nos deja claro cuál es su intención con nuestro problema: "Creo haber dado con la causa: tales inversiones sugieren que si los caracteres de una ficción pueden ser lectores o espectadores, nosotros, sus lectores o espectadores, podemos ser ficticios" (Borges, 2001, p. 49).

Después de este proceso, hemos visto cómo el autor nos ha jugado un movimiento que era imposible rechazarlo, y sentirnos transformamos en las apreciaciones de un Borges que aún determina nuestras relaciones con la literatura, con el mundo. Somos el rey de Babilonia que se pierde en el laberinto desértico en el relato "Los dos reyes y los dos laberintos".

\section{A manera de conclusión}

Siempre va a ser escaso nuestro entendimiento para completar una hermenéutica con Borges. Desde los mundos paralelos, y alter ego, la filosofía o la risa, nos carga de existir profundamente. Por encima de un suceso histórico también están los sucesos de Borges. Y el contenido de sus significaciones, en sus narraciones o poéticas, da una vestidura que consiste en desprenderse de nuestros conocimientos, o mejor dicho, no desprenderse, sino elaborar ese universo que Borges sigue creando con cada lectura que suscita y también el sentido de afirmación de la palabra.

Foucault (1999) encontró la paradoja de la Biblioteca de Borges como un asunto para evitar una nueva quema de la biblioteca universal. Una disposición de mantener la palabra viva y desprenderse de la indiferencia, incluso, del mismo autor. En este caso, de esa paradoja, el francés menciona que:

La literatura comienza cuando esta paradoja sustituye a aquel dilema; cuando el libro ya no es el espacio en el que la palabra cobra figura (figuras de estilo, figuras de retórica, figuras de lenguaje), sino el lugar en que los libros son retomados todos y consumidos. (p. 192)

Entonces, la literatura se define como dicha biblioteca, se define al escribirse, al retomarse. En ese desplazamiento de encasi- 
llar la definición nos encontramos con Borges. No se puede preguntar qué es la literatura, sino cómo abordamos la literatura. En este caso, se nos ofrece una perspectiva de la misma, de forma extensiva. No obstante, no es el vacío histórico que menciona William Ospina (2006, p.113) lo que hizo a Borges, Borges, es su compromiso con la palabra a través de sus juicios con el lenguaje en el que sabemos que el escritor argentino todavía habita.

Borges a través de su literatura explica lo metafísico, su alternancia con el lenguaje no subyace a la respuesta filosófica, es respuesta. Queda claro en las relaciones que sostuvimos que el argentino indaga desde lo literario como cuestión universal. Se trata entonces de un acercamiento para orientar otro estado global de la palabra.
En el momento que la literatura hace presencia, lo universal también. El objeto y definición de la literatura es ella misma, menciona Foucault (1996). Su compromiso no se concibe sin ella. Ciertamente, la literatura de Borges se puede definir como una biblioteca-laberinto para evidenciar que todavía se encuentra entre nosotros.

\section{Referencias}

Bahnsen, J. (2015). Lo trágico como ley del mundo y el humor como forma estética de lo metafísico. Valencia: Maite Simón.

Baudelaire, C. (1988). Lo cómico y la caricatura. (C. Santos, trad.). Madrid: Visor.

Barise, J., y Etchemendy, J. (1987). El mentiroso: un ensayo de la verdad y la circularidad. New York: Oxford.

Borges, J. L., Ocampo, S. y Casares, A. B. (1977). Antología de la literatura fantástica. Barcelona: Edhasa.

Borges, J. L. (1983). Narraciones. Bogotá: Oveja Negra.

Borges, J. L. (1984). Obras completas (14ª edición). Buenos Aires: Emecé.

Borges, J. L. (2001). Otras Inquisiciones. Bogotá: Biblioteca El Tiempo.

Borges, J. L. (2012). Historia de la eternidad. Bogotá: Penguin Random House.

Borges, J. L. (2016). El Aleph. Bogotá: Penguin Random House.

Coreth, E. (1972). Cuestiones fundamentales de hermenéutica. Barcelona: Herder Editorial.

Eco, U. (1998). Entre mentira e ironía (H. Millares, trad). Barcelona: Lúmen.

Espinosa, G. (1990). La liebre en la Luna. Bogotá: Tercer Mundo Editores. 
Foucault, M. (1996). De lenguaje y literatura. Barcelona: Paidos.

Foucault, M. (1999). Entre filosofía y literatura (M. Morey, trad.). Barcelona: Paidos.

Heidegger, M. (2014). ¿Qué es metafísica? Madrid: Alianza Editorial. https://doi.org/10.2307/j.ctvt9k21b

Jankélévitch, V. (1982). La ironía (R. Pochtar, trad.).Madrid: Taurus.

Kundera, M. (1994). Los testamentos traicionados. Barcelona: Tusquets Editores.

Man, P. d. (1996). El concepto de ironía. Valencia: Ediciones Episteme.

Malamud Goti, J. (2012). Tradición, heroísmo y sentido de la existencia: pensando en Borges y el mal. En Á. Uribe Botero y C. de Gamboa Tapias (eds.), Fuentes del mal (pp. 47- 81). Bogotá: Universidad Nacional de Colombia.

Martin, M. (2004).Humor y parodia en Borges: versiones de lo inverosímil. Variaciones Borges, 18, 4361. Recuperado de https://www.borges.pitt.edu/bsol/documents/1803.pdf

Ortega, J. (1977). Borges y la cultura hispanoamericana. Revista Iberoamericana, 43(100-101), 257268. https://doi.org/10.5195/REVIBEROAMER.1977.3542

Ospina, W. (2006). La decadencia de los dragones. Bogotá: Santillana, Punto de lectura.

Platón. (1988). República. Madrid: Gredos.

Ricoeur, P. (2017). Teoría de la interpretación (G. Monges, trad.). México D.F.: Siglo XXI.

SÁBAto, E. (1995). UNo Y EL UNIVERSo. Buenos Aires: Seix Barral.

Serna Arango, J. (1990). Borges y la filosofia. Pereira: Editorial Gráficas Olímpica.

Shopenhauer, A. (20 marzo 2020). El mundo como voluntad y representación (original publicado en 1819). Recuperado de http://www.juango.es/files/Arthur-Schopenhauer---El-mundo-como-voluntad-y-representacion.pdf

Stern, A. (1950). Filosofia de la risa y el llanto. Buenos Aires: Ediciones Imán.

Wittgenstein, L. (22 marzo 2020). Tractatus logico-filosóficus (original publicado en 1921). Recuperado de http://www.pensamientopenal.com.ar/system/files/2014/12/doctrina29684.pdf 